\title{
Pengaruh Media Flash Card terhadap Penguasaan Kosakata Bahasa Inggris Siswa Kelas III SD Inpres 109 Perumnas Kota Sorong
}

\section{Nur Wulan Ramadhanti ${ }^{1}{ }^{\circledR}$, Syams Kusumaningrum $^{2} \&$ Raisa $^{\text {Anakotta }}{ }^{3}$}

\author{
Prodi PGSD, Universitas Pendidikan Muhammadiyah Sorong, Indonesia
}

${ }^{凶}$ E-mail: wulanramadhantii98@gmail.com

\begin{abstract}
Abstrak
Penelitian ini bertujuan untuk mengetahui ada atau tidaknya pengaruh media flashcard terhadap penguasaan kosakata Bahasa Inggris siswa kelas III SD Inpres 109 Perumnas Kota Sorong. Penelitian ini merupakan penelitian eksperimen dengan menggunakan desain penelitian One Group PretestPosttest. Variabel bebas dalam penelitian ini adalah penggunaan media flashcard sedangkan variabel terikatnya adalah penguasaan kosakata Bahasa Inggris siswa kelas III SD Inpres 109 Perumnas Kota Sorong. Sampel dalam penelitian ini berjumlah 10 siswa. Teknik pengumpulan data yang digunakan adalah observasi kegiatan proses belajar, tes (pretest-posttest) dan dokumentasi. Teknik analisis data terdiri atas deskripsi data, uji normalitas, dan uji hipotesis. Hasil uji reliabilitas instrumen pretest diperoleh 0,926 dan hasil uji reliabilitas instrumen posttest diperoleh 0,791. Dari analisis data diperoleh uji normalitas Shapiro-wilk dari data pretest 0,501 dan posttest 0,087. Maka kedua data tersebut diperoleh data normal. Dari teknis analisis data nilai mean pretest 60,00 dan nilai mean posttest 82,50. Hasil uji One Sample t-test diperoleh nilai thitung > ttabel atau 17,542 > 2,262 dan hasil sig (2-teiled) < ttabel atau 0,000 < 0,05 maka H1 diterima dan $\mathrm{H} 0$ ditolak, sehingga dapat ditarik kesimpulan bahwa terdapt pengaruh pengaruh media flashcard terhadap penguasaan kosakata Bahasa Inggris siswa kelas III SD Inpres 109 Perumnas Kota Sorong.
\end{abstract}

Kata Kunci: Media Flashcard; Penguasaan Kosakata Bahasa Inggris; Siswa Kelas III

\begin{abstract}
This study aims to determine the existence or the effect of flashcard media to English students vocabulary at the third grade of SD INPRES 109 Perumnas Sorong City. This research is an experimental research with the design of one group pretest-posttest research. The independent variable in this research is the use of flashcard media, while the dependent variable is the mastery of English vocabulary students. The sample in this research consist of 10 students. The technique of collecting data used observation of learning process activities, tests (pretest-posttest) and documentation. The technique of data analyze consist of data descriptions, normality tests, and hypothesis tests. The test of reliable instrument reliability test was obtained by 0.926 and the test of relogy of the posttest instrument was obtained by 0.791 . From the data analysis obtained the form of the formality of Shapiro-wilk of the pretest data 0.501 and posttest 0.087. Then the second data is obtained by normality test. From technical data analysis of value of pretest 60.00 and the mean posttest mean 82.50. The results of one-sample t-test obtained $T$-value > T-table or $17.542>2.262$ and sig (2-tailed) $<$ T-table or $0.000<0.05$ then $\mathrm{HI}$ was accepted and $\mathrm{HO}$ was rejected, so it can be concluded that there was an effect of flashcard media to English students vocabulary for the third grade of SD Inpres 109 Perumnas Sorong City.
\end{abstract}

Keywords: Flashcard Media; English Vocabulary; Class III Students; 


\section{PENDAHULUAN}

Bahasa Inggris adalah alat untuk berkomunikasi baik secara lisan maupun tulisan. Dengan demikian, Bahasa Inggris berfungsi sebagai alat untuk berkomunikasi dalam rangka mengakses informasi selain sebagai alat untuk membina hubungan interpersonal, bertukar informasi serta menikmati estetika bahasa dalam budaya Inggris.

Pentingnya manusia mempelajari Bahasa Inggris adalah untuk dijadikan sebagai bekal di masa depan bagi dirinya sendiri, agar bisa bermanfaat bagi dirinya dan masyarakat luas dan bisa menerapkan ilmunya secara langsung kemasyarakat melalui tindakan-tindakan nyata yang merupakan hasil dari pembelajaran yang ia dapatkan di sekolah.

Sementara itu, masih banyak siswa yang mengalami kesulitan dalam mencapai suatu kompetensi dasar dan tujuan pengajaran itu sendiri. Hal ini dikarenakan penguasaan kosakata Bahasa Inggris siswa kurang memadai sehingga sangat berpengaruh pada pencapaian kompetensi. Mereka sering kesulitan memahami arti sebuah kata karena pemahaman kosakata mereka relatif kurang. Akibatnya proses pencapaian suatu kompetensi dasar akan berjalan lebih lama. Metode yang guru gunakan dalam pengajarannya pun kurang bervariasi dan mengakibatkan kurang berpengaruh dalam proses pembelajaran. Kurangnya media pembelajaran yang guru gunakan pada saat mengajar juga menjadi faktor selanjutnya yang menjadi kendala dalam proses pembelajaran.

Hal serupa juga terjadi di SD Inpres 109 Perumnas Kota Sorong. Apabila para siswa mengalami kesulitan dalam memahami arti sebuah kata selama proses pembelajaran, guru menyuruh siswa mencari arti kata tersebut dalam kamus atau memberitahu secara langsung arti dari kata tersebut. Cara tersebut terlalu sering digunakan sehingga berakibat kurang baik bagi para siswa karena hanya beberapa orang siswa yang memiliki kamus.

Melihat kendala-kendala tersebut dan fenomena yang ada di lapangan, maka penulis mencoba mencari cara untuk membantu meningkatkan penguasaan kosakata terutama pada siswa SD Inpres 109 Perumnas kelas III. Sebelumnya penulis memperhatikan sifat anak MI itu sendiri yang masih senang bermain.

Salah satu media yang bisa diterapkan sambil bermain adalah flashcard. Menurut Dewi Kuniawati (2014) Flashcard biasanya berukuran $8 \times 12 \mathrm{~cm}$, atau dapat disesuaikan dengan besar kecilnya kelas yang dihadapi oleh pendidik. Gambar-gambar yang terdapat pada flashcard merupakan rangkaian pesan yang disajikan dengan keterangan setiap gambar yang dicantumkan pada bagian belakangnya. Kelebihan dari media flashcard yaitu merupakan media grafis yang praktis dan aplikatif.

\section{METODE PENELITIAN}

Penelitian ini merupakan jenis penelitian kuantitatif eksperimen dengan PreExperimental Design. Penelitian ini melibatkan satu kelas sebagai kelas eksperimen dan perlakuan dengan tujuan untuk mengetahui pengaruh media flashcard terhadap penguasaan kosakata Bahasa Inggris.

Desain penelitian yang digunakan dalam penelitian ini adalah One Group Pretest-Posttest Design. Penelitian ini akan menggunakan dua macam variabel penelitian yaitu variabel independen (variabel bebas) yaitu $X$, dan variabel dependen (variabel terikat) yaitu Y. Sebagai variabel bebas (X) 
yaitu penggunaan media flashcard, dan sebagai variabel terikat (Y) yaitu penguasaan kosakata Bahasa Inggris.

\section{HASIL DAN PEMBAHASAN}

Dalam penelitian ini, peneliti memperoleh data dari hasil pretest dan posttest yang dilakukan pada kelas eksperimen. Pretest merupakan tes kemampuan yang diberikan kepada siswa sebelum diberi perlakuan, sedangkan posttest dilakukan setelah siswa mendapatkan perlakuan. Kedua tes ini berfungsi untuk mengukur sampai dimana pengaruh media flashcard terhadap penguasaan kosakata Bahasa Inggris siswa.

Sebelum melakukan pengambilan data, peneliti melakukan uji coba terhadap instrumen soal yang akan digunakan sebagai soal pretest dan posttest.

Penelitian ini menggunakan instrumen penelitian berupa tes berjumlah 10 butir soal melengkapi huruf kosakata. Sebelum soal diberikan kepada siswa di sekolah, terlebih dahulu dikonsultasikan dengan dua Profesional Judgment dosen PGSD Unimuda Sorong yang bernama Alman, M.Pd. dan Ahmad Yulianto, M.Pd. Setelah dilakukan perbaikan dan revisi dengan arahan dari validator terhadap instrumen tes yang telah disusun oleh peneliti, para ahli tersebut menyatakan bahwa instrumen tes yang telah dibuat tersebut telah layak digunakan.

Uji reliabilitas berasal dari kata reliability yang berarti hal yang dapat dipercaya (tahan uji). Reliabilitas digunakan untuk mengetahui apakah butir soal yang diujikan reliable (akurat dan tepat) dalam memberikan pengukuran terhadap siswa. Untuk menguji unstrumen reliabilitas peneliti menggunakan Software Statistic. Berikut ini adalah hasil uji reliabilitas pretest dan posttest :
Setelah di uji menggunakan analisis SPSS V20 didapatkan nilai Cronbach's Alpha pada instrumen pretest sebesar 0,926, dan posttest sebesar 0,791 hasil ini menunjukkan lebih besar dari ketentuan Cronbach's Alpha 0,6 dimana 0,926 > 0,6. dan $0,791>0,6$. Hal ini berarti instrumen pretest dan posttest memenuhi syarat reliabel dan dapat digunakan untuk penelitian.

Berdasarkan hasil analisis uji one smple t-test menunjukkan bahwa nilai $\mathrm{t}$ N_Gain_Persen sebesar 17,542 dengan Sig. (2-tailed) sebesar 0,000. Dikarenakan taraf signifikansi yang telah ditetapkan yaitu sebesar $0,000<0,05$ dan thitung sebesar 17,542 untuk taraf signifikansi 5\% dengan df $=10-1=9$ diperoleh ttabel (2,262). Dari data tersebut terlihat nilai thitung $>$ ttabel berarti $\mathrm{H} 1$ diterima dan $\mathrm{H} 0$ ditolak. Artinya media pembelajaran flashcard memiliki hasil yang lebih baik terhadap pengusaan kosakata Bahasa Inggris siswa kelas III SD Inpres 109 Perimnas Kota Sorong dibanding media pembelajaran yang digunakan guru selama ini.

Berdasarkan analisis persentase nilai mean statistic uji N-Gain adalah 56,4603 dan nilai tersebut berada antara rentang nilai 5676 , nilai yang terletak antara 56-76 termasuk dalam kategori cukup berpengaruh digunakan dalam proses pembelajaran Bahasa Inggris kelas III SD Inpres 109 Perumnas Kota Sorong. Uji N-Gain ini digunakan untuk mengetahui seberapa pengaruh dan meningkatnya hasil pembelajaran sebelum dan sesudah penggunakan media flashcard. Sedangkan uji One Sample t-Test digunakan untuk menguji kebenaran atau kepalsuan hipotesis yang menyatakan bahwa diantara dua buah mean sample yang diambil tidak terdapat perbedaan yang signifikan.

Uji One Sample t-Test digunakan untuk mengetahui apakah ada pengaruh 
antara penggunaan media flashcard terhadap kemampuan menulis dan melafalkan kosakata Bahasa Inggris siswa kelas III SD Inpres 109 Perumnas Kota Sorong.

$\mathrm{H}_{1}$ diterima jika signifikan $\leq 0,05$ dan $\mathrm{T}_{\text {hitung }} \geq \mathrm{T}_{\text {tabel}}$.

$\mathrm{H}_{0}$ diterima jika signifikan $\geq 0,05$ dan $\mathrm{T}_{\text {hitung }} \leq \mathrm{T}_{\text {tabel }}$.

$\mathrm{H}_{1}$ : Adanya pengaruh antara penggunaan media flashcard dengan penguasaan kosakata Bahasa Inggris siswa kelas III SD Inpres 109 Perumnas Kota Sorong.

$\mathrm{H}_{0}$ : Tidak adanya pengaruh antara penggunaan media flashcard dengan penguasaan kosakata Bahasa Inggris siswa kelas III SD Inpres 109 Perumnas Kota Sorong.

Berdasarkan hasil analisis data yang diperoleh dari perhitungan berkaitan dengan penelitian yang telah dilakukan di SD Inpres 109 Perumnas Kota Sorong pada kelas III A dengan jumlah sampel sebanyak 10 siswa. Dalam penelitian ini menggunakan instrumen lembar observasi kegiatan inti siswadi dlam kelas.

Instrumen tes penggunaan media flashcard berjumlah 10 butir soal. Dapat diketahui bahwan hasil penelitian ini mempunyai pengaruh terhadap penguasaan kosakata Bahasa Inggris siswa kelas III SD Inpres 109 Perimnas Kota Sorong.

Berdasarkan hasil perhitungan analisis deskriptif bahwa indikator perasaan senang, memperoleh jawaban tertinggi yaitu sebanyak 10 siswa yang berarti semua siswa menyukai pembelajaran dengan menggunakan media flashcard hal ini disebabkan media flashcard membuat siswa menjadi lebih cepat memahami kosakata Bahasa Inggris karena siswa langsung melihat gambar asli dari kosakata tersebut beserta ejaan dari masing-masing kosakata. Jadi dapat disimpulkan adanya pengaruh penggunaan media flashcard terhadap penguasaan kosakata Bahasa Inggris siswa kelas III SD Inpres 109 Perumnas Kota Sorong.

Dapat diketahui hasil penelitian ini berpengaruh antara penggunaan media flashcard terhadap penguasan kosakata Bahasa Inggris, yang diketahui nilai rata-rata pretest sebesar 60,00 dan nilai rata-rata posttest sebesar 82,50. Berdasarkan nilai tesebut terdapat peningkatan sesudah melakukan treatment menggunakan media flashcard.

Penelitian ini menggunakan beberapa uji untuk mendapatkan hasil data yang diinginkan yaitu uji validitas dan uji reliabilitas. Perhitungan uji reliabilitas menggunakan SPSS diperoleh hasil pretest 0,926 dan hasil posttest 0,791. Berdasarkan kriteria tes dikatakan reliabel jika nilai Cronbach's Alpha lebih besar 0,6. 0,926 > 0,6 dan $0,791<0,6$ maka instrumen tes telah memenuhi syarat reliabel.

Hasil penelitian dari uji normalitas menggunakan rumus Shapiro Wilk diketahui pengolahan data uji normalitas diperoleh dari perhitungan menggunakan SPSS V 20 diketahui hasil belajar pretest memiliki nilai sig sebesar 0, ,501 dimna Asymp,Sig > 0,05 dan hasil posttest memiliki nilai sig sebesar 0,087 dimana Asymp,Sig > 0,05 sehingga dapat disimpulkan bahwa data berdistribusi normal dan layak digunakan untuk uji hipotesis.

Sebelum dilakukan Uji One Sample ttest terlebih dahulu dilakukan Uji N-Gain untuk melihat perhitungan skor N-Gain dan perhitungan pengaruh N-Gain. Dari data tabel di atas dapat dianalisis bahwa persentase nilai mean statistic N-Gain adalah 56,4603 dan nilai tersebut berada antara 
rentang nilai 56-76, nilai yang terletak antara 56-76 termasuk dalam kategori cukup berpengaruh digunakan dalam proses pembelajaran Bahasa Inggris kelas III SD Inpres 109 Perumnas Kota Sorong.

Berdasarkan hasil analisis uji one sample t-test menunjukkan bahwa nilai $\mathrm{t}$ N_Gain_Persen sebesar 17,542 dengan Sig. (2-tailed) sebesar 0,000. Dikarenakan taraf signifikansi yang telah ditetapkan yaitu sebesar $0,000<0,05$ dan thitung sebesar 17,542 untuk taraf signifikansi 5\% dengan df $=10-1=9$ diperoleh ttabel (2,262). Dari data tersebut terlihat nilai thitung $>$ ttabel berarti $\mathrm{H} 1$ diterima dan $\mathrm{H} 0$ ditolak, maka hipotesis diterima dan disimpulkan bahwa terdapat pengaruh terhadap pengusaan kosakta Bahasa Inggris siswa kelas III SD Inpres 109 Perimnas Kota Sorong.

\section{KESIMPULAN}

Berdasarkan hasil analisis data, pengujian hipotesis dan pembahasn yang telah dikemukakan pada bab sebelumnya dalam penelitian eksperimen yang mendapat pengajaran menggunakan media flashcard pada meteri going shopping terhadap penguasaan kosakata siswa kelas III SD Inpres 109 Kota Sorong, maka dapat disimpulkan penelitian sebagai berikut :

Terdapat perbedaan mean (nilai ratarata) antara nilai pretest dan posttest atau nilai sebelum ada perlakuan dan nilai sesudah perlakuan. Dari perhitungan nilai mean pretest sebesar 60,00 dan nilai mean posttest sebesar 82,50, berdasarkan nilai pretest dan posttest ini dapat diambil kesimpulan bahwa dengan media flashcard dapat mempengaruhi penguasaan kosakata Bahasa Inggris siswa.

Media flashcard terbukti memiliki pengaruh terhadap penguasaan kosakata Bahasa Inggris siswa kelas III SD Inpres 109
Kota Sorong. Dari perhitungan diperoleh thitung > ttabel yaitu 17,542>2,262, dapat disimpulkan bahwa $\mathrm{H} 1$ diterima atau media flashcard memiliki pengaruh terhadap penguasaan kosakata Bahasa Inggris siswa, dan H0 ditolak.

\section{DAFTAR RUJUKAN}

Arikunto. 2010. "Prosedur Penelitian Suatu Pendekatan Praktek." Jakarta: Rineka Cipta.

Fitriyani, Eka, and Putri Zulmi Nulanda. 2017. "Efektivitas Media Flash Cards

Dalam Meningkatkan Kosakata Bahasa Inggris." 4(2): 167-82.

Hotimah, Empit. 2010. "Penggunaan Media Flashcard Dalam Meningkatkan Kemampuan Siswa Pada Pembelajaran Kosakata Bahasa Inggris." Jurnal Pendidikan Universitas Garut 04(01): 10-18. www.journal.uniga.ac.id.

Juliani, silfi Eka. 2014. "Efektifitas Permainan 'Im Drierpack' Untuk Meningkatkan Penguasaan Kosakata Bahasa Jerman Universitas Pendidikan Indonesia | Repository.Upi.Edu | Perpustakaan.Upi.Edu." : 6-26.

Lestari, Ikmala Yunita. 2012. "Upaya Peningkatan Penguasaan Kosakata Bahasa Inggris Anak Melalui Media Kartu Gambar (Flash Card) Pada Kelompok B Di RA Barokah Klodran Karanganyar Tahun Pelajaran 2011/2012." : 139.

Marlianingsih, Noni. 2016. "Pengenalan Kosa Kata Bahasa Inggris Melalui Media Audio Visual ( Animasi ) Pada Paud." 3(2): 133-40.

Nursalam. 2013a. "Pengembangan Media English Card Vovcabulary Dalam Pembelajaran Kosakata Bahasa Inggris Untuk Siswa Kelas III SDN Dinoyo 3 Malang." Journal of Chemical Information and Modeling 53(9): 1689-99.

Nursalam. 2013b. "Penggunaan Media Flash Card Dalam Upaya Meningkatkan Penguasaan Kosakata Pada Anak Kelompok B Taman Kanak-Kanak 
Kuncup Melati I Grogol VIII,
Parangtritis, Bantul." Journal of Chemical Information and Modeling 53(9): 1689-99.

Rizki Ayu Fatimah Ridwan. 2018. Efektivitas Penerapan Pendekatan Savi Setting Cooperative Script Dalam Pembelajaran Matematika Siswa Kelas Ix SMP Negeri 33 Makassar.

Sekarini, Wining. 2018. "Penggunaan Media Flash Card Untuk Meningkatkan Kemampuan Menghafal Kosa Kata Bahasa Arab Siswa Madrasah Ibtidaiyah Terpadu Muhammadiyah 01 Sukarame." 10(2): 1-15.
Susanto, Yohana Dini Trisnani. 2017. "Hubungan Penguasaan Kosakata Dengan Keterampilan Berbicara Dan Menulis Siswa Kelas IV SDN Gugus Pangeran Diponegoro Kecamatan Ngaliyan."

Talizaro Tafonao. 2018. "Peranan Media Pembelajaran Dalam Meningkatkan Minat Belajar Mahasiswa." 2(2).

Wulansari, Eva. 2014. "Keefektifan Penggunaan Media Flashcard Dalam Pembelajaran Keterampilan Menulis Bahasa Jerman Di SMA Negeri 1 Sedayu Bantul." 6(4). 